\title{
Influence of water deficit on the induced and constitutive responses of pines to infection by mountain pine beetle fungal associates
}

\author{
Adriana Arango-Velez*, Miranda Meents, Jean Linsky, Walid El Kayal, Eri Adams, Leonardo Galindo, Janice Cooke \\ From IUFRO Tree Biotechnology Conference 2011: From Genomes to Integration and Delivery \\ Arraial d'Ajuda, Bahia, Brazil. 26 June - 2 July 2011
}

\section{Background}

The ongoing outbreak of mountain pine beetle (MPB; Dendroctonus ponderasae Hopkins) and its associated pathogenic fungi (e.g. Grosmannia clavigera [RobinsonJeffrey and Davidson] Zipfel, de Beer and Wingfield) in western North America has resulted in the loss of more than 13 million hectares of pines since 1999 in British Columbia alone [1]. MPB has principally attacked lodgepole pine (Pinus contorta Dougl. ex Loud. var. latifolia) in British Columbia. However, since 2006 MPB has spread into northern Alberta, where lodgepole pine hybridizes with jack pine (Pinus banksiana Lamb.) [2]. Few studies have compared lodgepole and jack pine defense responses, but given that lodgepole pine and MPB share a co-evolutionary history [1] whereas jack pine is a new host for MPB [2], it is reasonable to expect that differences might exist. Some regions affected by the current outbreak have experienced drought conditions during the last decade. Water deficit can limit carbon assimilation, potentially increasing tree susceptibility to MPB and their symbiotic fungi [3]. We are testing the hypotheses that lodgepole and jack pine defenses against MPB and G. clavigera differ, and that water deficit affects these responses.

\section{Materials and methods}

The relationship between water availability and tree defense was evaluated in (1) two year old lodgepole and jack pine seedlings in growth rooms, and (2) ca. sixty year old lodgepole $\mathrm{x}$ jack pine hybrids in naturally regenerated, thinned stands. Soil relative water content was monitored using time-domain reflectometry.

\footnotetext{
* Correspondence: adrianaa@ualberta.ca

Department of Biological Sciences, University of Alberta, Canada
}

Seedlings were subjected to watering or water deficit for one week prior to wounding or wounding plus G. clavigera inoculation. Mature trees were either watered or water limited via tarps for six weeks before wounding plus G. clavigera inoculation. In both experiments, water deficit conditions were maintained throughout the time course.

Tree physiological status was evaluated by measuring gas exchange and stomatal conductance using a LiCor 6400 , stem hydraulic conductivity using a low-pressure flow meter and safranin dye xylem perfusion, and HPLC. Defense responses were assessed by lesion measurements histochemistry, and qRT-PCR.

\section{Results and discussion}

Stomatal conductance and photosynthesis significantly decreased under water deficit for both lodgepole and jack pine seedlings, but seedling hydraulic conductivity was not affected. The mild water deficit applied to the mature trees reduced stomatal conductance and photosynthesis, but not significantly.

Stem lesions are a means of killing and compartmentalizing invading organisms [4]. G. clavigera-induced lesions developed more slowly in jack pine than lodgepole pine seedlings. Stem hydraulic conductivity decreased in inoculated lodgepole but not jack pine seedlings, likely because of greater tracheid occlusion caused by increased fungal growth and/or resin production in lodgepole pine [5]. Water deficit reduced lesion development rates at early time points in inoculated lodgepole and jack pine seedlings, as well as in mature trees at 5 weeks post-inoculation. Lesion length has been considered an indicator of tree defense capacity [6], with longer lesions reported to reflect increased release of toxic and/or inhibitory substances [7]. Accordingly, we 
interpret slower lesion development to indicate a slower defense response. Our results suggest (1) more rapid defense responses to G. clavigera in the co-evolved lodgepole pine host than in the new jack pine host, and (2) defense responses are slowed by water limitation.

We then examined the effect of water deficit on transcript abundance corresponding to genes classically associated with drought and defense responses. We conducted qRT-PCR transcript abundance profiling of secondary phloem from mature lodgepole $\mathrm{x}$ jack pine hybrids. We first profiled four aquaporin and five DREB genes, families associated with water stress responses. Although the mild water deficit did not significantly alter expression of these genes, expression of one aquaporin and one DREB decreased in response to G. clavigera inoculation. We then profiled five chitinase and four terpene synthase defense-associated genes. Expression of two chitinases was significantly induced by water deficit but not G. clavigera. Expression of other chitinases significantly increased in response to fungalinoculation, but the response was attenuated by water deficit. Expression of one terpene synthase significantly increased with fungal inoculation, but this response was also attenuated under water deficit. In contrast, water deficit increased constitutive expression of another terpene synthase. Higher constitutive expression of the monoterpene synthase under mild water stress suggests a pre-emptive defense via higher biosynthesis of volatile monoterpenes. Microarray and qRT-PCR analyses of the lodgepole and jack pine seedling experiment are underway.

\section{Conclusion}

Our analyses suggest that defense responses of jack pine differ from those of lodgepole pine. Molecular analyses are underway to further characterize these differences. Both constitutive and induced defense responses are modulated in pines by water deficit, and this response appears to be gene-specific. This study shows evidence of cross talk between the water stress and defense responses of pine trees.

Published: 13 September 2011

\section{References}

1. Raffa KF, Aukema BH, Bentz BJ, Carroll AL, Hicke JA, Turner MG, Romme WH: Cross-scale drivers of natural disturbances prone to anthropogenic amplification: the dynamics of bark beetle eruptions. Bioscience 2008, 58:501-517.

2. Cullingham Cl, Cooke JEK, Dang S, Davis CS, Cooke BJ, Coltman DW: Mountain pine beetle host-range expansion threatens the boreal forest. Mol Ecol 2011, 20:2157-2171.

3. McDowell N, Pockman WT, Allen CD, Breshears DD, Cobb N, Kolb T, Plaut J, Sperry J, West A, Williams DG, Yepez EA: Mechanisms of plant survival and mortality during drought: why do some plants survive while others succumb to drought? New Phytol 2008, 178:719-739.
4. Franceschi VR, Krokene P, Christiansen E, Krekling T: Anatomical and chemical defenses of conifer bark against bark beetles and other pests. New Phytol 2005, 167:353-376.

5. Joseph G, Kelsey RG, Thies WG: Hydraulic conductivity in roots of ponderosa pine infected with black-stain (Leptographium wageneri) or annosus (Heterobasidion annosum) root disease. Tree Physiol 1998, 18:333-339.

6. Paine TD, Stephen FM: Influence of tree stress and site quality on the induced defense system of loblolly pine. Can J For Res 1987, 17:569-571.

7. Raffa KF, Berryman AA: Physiological aspects of lodgepole pine wound response to a fungal symbiont of the mountain pine beetle Dendroctonus ponderaseae. Can Entomol 1983, 115:723-734.

doi:10.1186/1753-6561-5-S7-O29

Cite this article as: Arango-Velez et al:: Influence of water deficit on the induced and constitutive responses of pines to infection by mountain pine beetle fungal associates. BMC Proceedings 2011 5(Suppl 7):O29.

\section{Submit your next manuscript to BioMed Central} and take full advantage of:

- Convenient online submission

- Thorough peer review

- No space constraints or color figure charges

- Immediate publication on acceptance

- Inclusion in PubMed, CAS, Scopus and Google Scholar

- Research which is freely available for redistribution 